\section{The effect of relative prey size on the ingestion behavior of rodent-eating snakes*}

\author{
MICHAEL S. LOOP and LAWRENCE G. BAILEY \\ Florida State University, Tallahassee, Fla. 32306
}

Six species of snakes from three families that represent diverse phyletic position and prey-capture techniques were fed mice of different sizes. The probability of the prey-capture technique's being employed and of headfirst ingestion were determined by relative meal size, i.e., ingestion ratio. When dealing with relatively large prey, all constrictors and venomous species reliably located the head prior to ingestion.

There is fairly general agreement that the ability of snakes to ingest comparatively large prey has itself played an important role in their overall success and has been a crucial factor in the development of associated feeding modification, i.e., constriction and venom (Schmidt, 1950; Bellairs \& Underwood, 1951; Gans, 1961), which have also played an important role in their evolutionary history. For the most part, attention has been focused on the anatomical changes which have accounted for the increased ingestion capacity of the snakes (Gans, 1961). There exists, however, at least one behavioral tendency in the feeding pattern of snakes which contributes to their ability to swallow comparatively large prey animals, namely, ingesting prey headfirst. The tendency of snakes to eat their prey headfirst has been a widespread observation (Bellairs, 1970; Klauber, 1956; Nalleau, 1966). The typical comment is that snakes usually ingest their prey headfirst to lessen the resistance presented by the limbs and body surface cover (hair, feathers) and thereby increase the range of consumable prey. Head-first ingestion of prey, however, has only recently been substantiated experimentally by Diefenbach \& Emslie (1971). These investigators demonstrated that Elaphe climacophora reliably swallowed mice headfirst when the mice were larger in diameter than the snake's head. Diefenbach and Emslie went on to attempt an analysis of the crucial stimuli utilized by the snakes in locating the head, but were only able to suggest that Elaphe "may utilize both tactile and chemical stimuli in determining the place to initiate ingestion."

While Diefenbach \& Emslie (1971) have made a step in the right direction, their study is limited to one species of modern constrictor. Headfirst ingestion has been reported in a much wider range of snake species. Furthermore, from these data it is not

* This research was supported by the Psychobiology Research Center, Florida State University, through Grant GU-2612. possible to determine whether the snakes are actually locating the prey's head prior to initiating ingestion or whether the head is arrived at in a trial and error fashion. In addition, Diefenbach and Emslie neglected to analyze systematically the effect of prey size, which is of paramount importance in predicting whether a given meal will be ingested headfirst. The following study was conducted to clarify these issues.

\section{SUBJECTS}

A total of 18 snakes were employed: two primitive constrictors, Indian Rock Pythons $(\mathrm{N}=2)$ (Python molurus) and boa constrictors $(\mathrm{N}=3$ ) (Constrictor constrictor); two modern constrictors, rat snakes $(\mathrm{N}=3)$ (Elaphe obsoleta) and California king snakes $(\mathrm{N}=2)$ (Lampropeltis getulus californiae); one modern species employing a body-pin prey-capture technique, indigo snakes $(\mathrm{N}=5)$ (Drymarchon corais); and one venomous species, Eastern diamondback rattlesnakes $(\mathrm{N}=3)$ (Crotalus adamenteus). All of the Ss were experienced feeders at the beginning of the study, with the possible exception of the three rattlesnakes, which were probably born just prior to capture.

\section{Procedure}

The experimental procedure involved offering one live preweighed mouse at a time to a given snake. If the snake ate the mouse, the following observations were made: (1) use of species-typical prey-capturing technique, i.e., constriction (pythons, boas, rat snakes, king snakes), venom (rattlesnakes), or body pinning (indigo snakes); (2) location on the mouse's body where the snake's mouth first opened prior to ingestion; (3) direction of ingest, i.e., headfirst, tail first, or side first.

The independent variable employed was the size of the mouse relative to the size of a given snake's head. Mouse size was defined as the diameter in inches of the largest circular hole through which a dead mouse of a particular weight could not be passed headfirst with a modest amount of pressure. This procedure was employed to construct Fig. 1, which illustrates the relationship between mouse weight and caliber. As can be seen, a 2-g and a 30-g mouse corresponded to calibers of .35 and .81 , respectively. A similar procedure was employed to measure the head size of each snake. This head size was also expressed as a decimal fraction of inches or caliber. It was then possible to quantify the relative meal size for each $S$ by employing a formula: ingestion ratio $=$ mouse caliber $/$ snake caliber. The ingestion ratio yielded larger values for relatively larger meals for a given snake. More importantly, however, the ingestion ratio provided a means of determining what constituted equal relative meal sizes for snakes of different absolute head sizes.

A total of 97 meals were observed: boas and pythons, 30 meals, ingestion ratio range .38 to 1.10 ; indigo snakes, 38 meals, ingestion ratio range .40 to 1.04; rat snakes and California king snakes, 22 meals, ingestion ratio range .49 to 1.64; Eastern diamondback rattlesnakes, 7 meals, ingestion ratio range .63 to 1.13 . The sequence of meal sizes for any one snake was haphazard. Whenever possible, mice of a variety of sizes were offered to a snake during a feeding session.

\section{RESULTS}

Table 1 presents the probability of headfirst ingestion and use of prey-capture technique for the four groups defined by phyletic position and prey-capture technique, i.e., primitive constrictors (boas and pythons); modern constrictors (rat snakes and king snakes); modern species employing a body-pin capture technique (indigo snakes); and modern venomous species (rattlesnakes).

The probability of either event at a given ingestion ratio was calculated as the percentage of total meals (within \pm .10 ingestion ratio units) on which the event occurred. This sliding bin analysis was employed to maximize the number of meals included at any given ingestion ratio within a meaningful range.

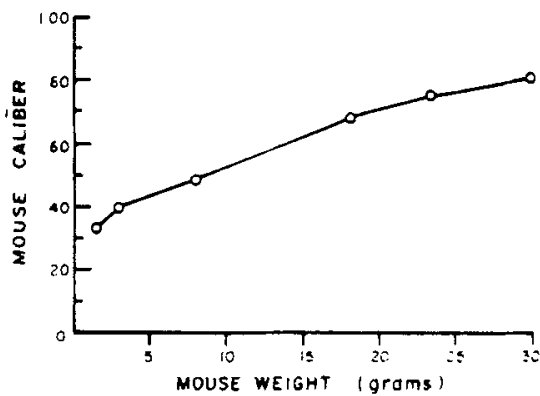

Fig. 1. Relationship between mouse weight in grams and mouse caliber in decimal inches. 
Table 1

Probability of Head-First Ingestion (H) and Prey Capture (C) for Each Phyletic PositionCapture Technique Group as Determined by the Ingestion Ratio

\begin{tabular}{|c|c|c|c|c|c|c|c|c|c|c|}
\hline \multirow{2}{*}{$\begin{array}{c}\text { Phyletic-Capture } \\
\text { Group }\end{array}$} & & \multicolumn{9}{|c|}{ Ingestion Ratio } \\
\hline & & .40 & .50 & .60 & .70 & .80 & .90 & 1.0 & 1.1 & $1.2+$ \\
\hline Python and Boa & $\begin{array}{l}\mathrm{H} \\
\mathrm{C}\end{array}$ & $\begin{array}{l}.40 \\
.40\end{array}$ & $\begin{array}{l}.50 \\
.60\end{array}$ & $\begin{array}{l}.57 \\
1.0\end{array}$ & $\begin{array}{l}.88 \\
1.0\end{array}$ & $\begin{array}{l}1.0 \\
1.0\end{array}$ & $\begin{array}{l}1.0 \\
1.0\end{array}$ & $\begin{array}{l}1.0 \\
1.0\end{array}$ & $\begin{array}{l}1.0 \\
1.0\end{array}$ & $\begin{array}{l}1.0 \\
1.0\end{array}$ \\
\hline Rat and King Snake & $\begin{array}{l}\mathrm{H} \\
\mathrm{C}\end{array}$ & & & $\begin{array}{l}.60 \\
.00\end{array}$ & $\begin{array}{l}.83 \\
.17\end{array}$ & $\begin{array}{l}.75 \\
.50\end{array}$ & $\begin{array}{l}1.0 \\
1.0\end{array}$ & $\begin{array}{l}1.0 \\
1.0\end{array}$ & $\begin{array}{l}1.0 \\
1.0\end{array}$ & $\begin{array}{l}1.0 \\
1.0\end{array}$ \\
\hline Indigo Snake & $\begin{array}{l}\mathrm{H} \\
\mathrm{C}\end{array}$ & $\begin{array}{l}.25 \\
.00\end{array}$ & $\begin{array}{l}.30 \\
.30\end{array}$ & $\begin{array}{l}.60 \\
.69\end{array}$ & $\begin{array}{l}.94 \\
.90\end{array}$ & $\begin{array}{l}.89 \\
1.0\end{array}$ & $\begin{array}{l}1.0 \\
1.0\end{array}$ & $\begin{array}{l}1.0 \\
1.0\end{array}$ & & \\
\hline Rattlesnake & $\begin{array}{l}\mathrm{H} \\
\mathrm{C}\end{array}$ & & & $\begin{array}{l}1.0 \\
1.0\end{array}$ & $\begin{array}{l}1.0 \\
1.0\end{array}$ & $\begin{array}{l}1.0 \\
1.0\end{array}$ & $\begin{array}{l}1.0 \\
1.0\end{array}$ & $\begin{array}{l}1.0 \\
1.0\end{array}$ & & \\
\hline
\end{tabular}

Figure 1 presents the relationship between the probability of head-first ingestion (Function 1) and the probability of the species-specific prey-capture technique's being employed (Function 2) as related to ingestion ratio. Probabilities were determined by combining the data of all Ss and were calculated as for Table 1.

It is clear from these data that the tendency to ingest mice headfirst was unanimous when the snakes were dealing with relatively large mice regardless of phyletic position or prey-capture technique. The group data (Function 1) reached statistical reliability at an ingestion ratio of .60 $\left(x^{2}, .02<p<.05\right)$. Furthermore, the entire probability range from chance, .33 , to 1.00 was mapped between ingestion ratios .40 to .80 . The relationship between the probability of the species-specific prey-capture technique being employed and the ingestion ratio (Function 2) was virtually identical to the probability of head-first ingestion $(p<.05$, Hotelling and Pabst's test for rank-order

\section{FUNCTION ।}
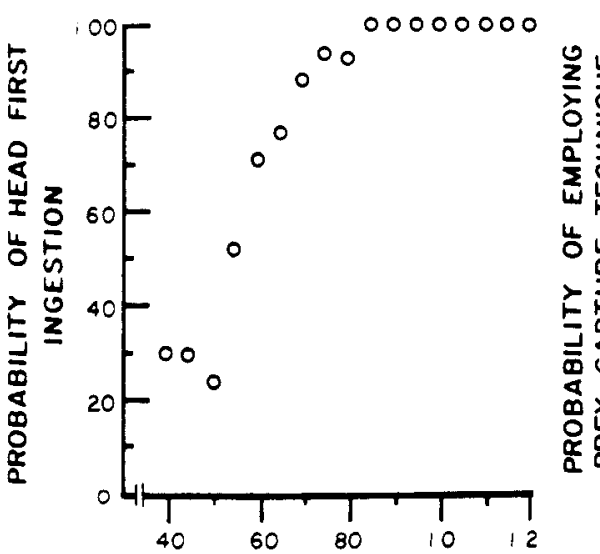

correlation) and reached statistical reliability at an ingestion ratio of .65 $\left(x^{2}, p<.01\right)$. On those meals which did not elicit the species prey-capture technique, the mouse was simply swallowed. When attention was turned to the range of ingestion ratios always eliciting prey capture and head-first ingestion, the four groups behaved as follows.

The four species employing constriction followed the same overall pattern. First, the snake seized the mouse in its mouth, encircled it with one or more coils, and retained this hold until the mouse had succumbed to suffocation. The boas and pythons reliably attacked the head of the mouse more often than the back $\left(x^{2}\right.$, $.01<\mathrm{p}<.02)$. The rat snakes and king snakes attacked the head more often but not reliably $\left(x^{2}\right.$, $.10<\mathrm{p}<.50$ ). Following the death of the mouse, if the snake did not already have the mouse's head, it was released. The boas and pythons first reopened their mouths, prior to ingestion, on the mouse's head reliably more often than elsewhere $\left(x^{2}, .01<p<.02\right)$, as

\section{FUNCTION 2}

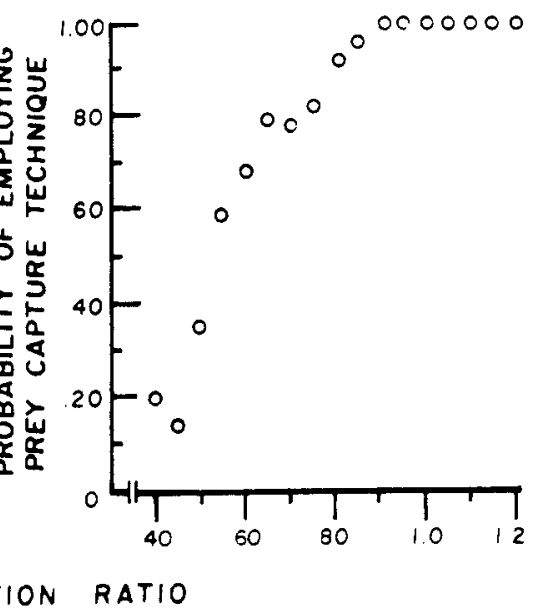

Fig. 2. Relationship between the probability of a mouse's being ingested headfirst and the probability of the snake's employing its species-specific prey-capture technique as a function of ingestion ratio mouse caliber/snake caliber. did the rat snakes and king snakes $\left(\chi^{2}\right.$, $.05<\mathrm{p}<.10)$. The indigo snakes seized the mouse, pinned it to any available surface with the mid portion of their body, but did not release the mouse between the initial strike and subsequent ingestion. Initial contact occurred at the mouse's head on $24 \%$ of the meals, at the back on $29 \%$, and somewhere in the middle on $47 \%$. Despite the random location of the initial strike, the indigo snakes always managed to find the head. On the occasions when the mouse's head was not initially seized, the mouse was manipulated through the snake's mouth until the head was located. The rattlesnakes struck and immediately released the mouse. After the initial bite, the rattlesnakes explored the dead mouse and reliably first opened their mouths at the mouse's head $\left(x^{2}\right.$. $.05<\mathrm{p}<.10$ ).

\section{DISCUSSION}

The results of this study indicate that the tendency to ingest relatively large mammalian prey headfirst was common to all six species investigated, despite differences in phyletic position and prey-capture techniques. When dealing with large prey that was killed and released, ingestion was reliably initiated at the head, indicating that the constrictors and venomous species were capable of recognizing the mouse's head. The primitive constrictors, boas and pythons, reliably gripped the mouse's head on the initial strike, while the rat snakes, king snakes, and indigo snakes did not.

The relative size of the meal, as indicated by the ingestion ratio, clearly controlled the probability of both headfirst ingestion and employment of the prey-capture technique for all the nonvenomous species. The only major discrepancy between the nonvenomous snakes appears to have been their range of meal sizes that elicited the prey-capture technique. The boas and pythons always constricted mice representing ingestion ratios above .50 . The indigo snakes always employed their body-pin capture technique above ingestion ratios of .70 , while the rat snakes and king snakes consistently constricted the mice above an ingestion ratio of .80 . This difference between the nonvenomous groups may be accounted for by the absolute size of the snakes. Since the boas and pythons were the largest, the indigo snakes next, and the rat and king. snakes smallest, the absolute size of the mice employed in equal ingestion ratios also differed. Therefore, at equal ingestion ratios, the boas and pythons were dealing with mice of an absolute larger size that were also more active 
and better equipped to defend themselves.

The rattlesnakes killed and ate all seven meals headfirst regardless of relative size within the ingestion ratio range of .63 to 1.13 . These snakes were captured in the early fall and gave no signs (defecation) of having eaten recently. Their reliable location of the head prior to attempted ingestion, coupled with the probability that these meals were their first, suggests that the behavior may be innate. The stimuli mediating discrimination of the head still remain unclear.

\section{REFERENCES}

BELLAIRS, A. d'A. The life of reptiles. New York: Universe Books, 1970

BELLAIRS, A d'A., \& UNDERWOOD, G. The origin of snakes. Biological Review, 1951 , XXVI, 193-237.

DIEFENBACH, C. O.. \& EMSLIE, S. G. Cues influencing the direction of prey ingestion of the Japanese snake, Elaphe climacophora (Colubridae, Serpentes). Herpetologica, 1971, 27, 461-466.

GANS, C. The feeding mechanism of snakes and its possible evolution. American Zoologist, 1961, 1, 217-227.

KLAUBER, L. M. Rattlesnakes: Their habits, life histories, and influence on mankind. Berkeley and Los Angeles: University of California Press, 1956.

NAULLEAU, G. La biologie et le comportement predateur de Vipera aspis au laboratoire et dans la nature. Thesis. University of Nancy, Fanlae, Périgueux, 1966.

SCHMIDT, K. P. Modes of evolution discernible in the taxonomy of snakes. Evolution, 1950, 4, 79-86. 